\title{
Intellectual Capital and Financial Performance: The Role of Good Corporate Governance (Study on Islamic Banking in Indonesia)
}

\section{Jummaini ${ }^{1,2}$, Nasir Azis ${ }^{3}$, Faisal ${ }^{3}$, and Hasan Basri ${ }^{3}$}

${ }^{1}$ Doctoral Student of Management, Faculty of Economics and Business, University of Syiah Kuala, Aceh, Indonesia

${ }^{2}$ Lecturer of Faculty of Economics and Business, Department of Management, University of Malikussaleh, Aceh, Indonesia

${ }^{3}$ Lecturer of Faculty of Economics and Business, Department of Management, University of Syiah Kuala, Aceh, Indonesia

\section{Abstract}

The main objective of this research is to analyze the impact of the efficiency of

Corresponding Author:

Jummaini

jummaini@gmail.com

Received: 18 January 2019

Accepted: 24 March 2019

Published: 31 March 2019

Publishing services provided by Knowledge E

(c) Jummaini et al. This article is distributed under the terms of the Creative Commons.

Attribution License, which permits unrestricted use and redistribution provided that the original author and source are credited.

Selection and Peer-review under the responsibility of the First ELEHIC Conference Committee.
Good Corporate Governance and Intellectual Capital on Financial Performance of Sharia Banking Companies in Indonesia. A new instrument is needed, Good Corporate Governance in a more efficient management process. The variables on Good Corporate Governance (GCG) studied (ie: the responsibilities and capabilities of the Sharia Supervisory Board, Independence and External Auditor's Ability, Involvement of Investment Account Holders in the Board of Directors) are expected to further improve the Company's Financial Performance. These variables are important to be tested and limitations in previous studies, which only tested Good Corporate Governance in terms of the size of the Sharia Supervisory Board, the Size of the Board of Directors and the Independence of the External Auditor. Also expand the Intellectual Capital literature by analyzing the impact of intellectual capital investment on the company's financial performance. Intellectual Capital to be studied are the main components based on the company's resources (ie physical capital, human capital and structural capital) which is expected to affect the five dimensions of the company's financial performance: Return on total assets (ROA), Profit Sharing Ratio (PSR), Zakat Performance Ratio (ZPR), Equitable Distribution Ratio (EDR), Islamic Income Vs Non- Islamic Income. Data were obtained from 13 sharia banks in Indonesia for three periods, 2012-2016. This study examines Good Corporate Governance, three elements of VAIC ${ }^{T M}$ (physical capital, human capital and structural capital) and measures of company's financial performance by using Partial Least Squares (PLS) for data analysis.

Keywords: Good Corporate Governance, Intellectual Capital, VAIC, Financial Performance. 


\section{Introduction}

The main objective of this study is to analyze the impact of the efficiency of Good Corporate Governance (ie: the responsibilities and capabilities of the Sharia Supervisory Board, Independence and External Auditor's Ability, Involved Account Ownership Ownership in the Board of Directors), and Intellectual Capital consisting of key components based on company resources (ie physical capital, human capital and structural capital) on five dimensions of the company's financial performance: Return on total assets (ROA), Profit Sharing Ratio (PSR), Zakat Performance Ratio (ZPR), Equitable Distribution Ratio (EDR),

Islamic Income Vs Non-Islamic Income. This study also aims to verify the influence of Good Corporate Governance on the Company's Intellectual Capital (IC) Performance.

Performance disclosure is closely related to the concept of Good Corporate Governance (GCG). The concept of GCG emphasizes more on the internal balance between corporate organs (owners of capital / stock, commissioners and directors) relating to institutional structures and operational mechanisms and external balance or corporate social concerns to the community and stakeholders in order to gain legitimacy and positive value. According to Sutedi (2011) [1], Corporate Governance is a process and structure used by company organs (Owners of Shares / Capital Owners, Commissioners / Supervisory Board, and Board of Directors) to improve business success and corporate accountability in order to realize shareholder value in the long term with fixed attention to the interests of other stakeholders, based on legislation and ethical values.

The new instrument of Good Corporate Governance with the variables of responsibility and ability of Sharia Supervisory Board, Independence and External Auditor's Ability, and Involvement of Investment Account Owner in Board of Directors, is very interesting to study. Considering these variables are considered very important in performance improvement and a limitation in previous studies, which tested Good Corporate Governance in terms of Sharia Supervisory Board Size, Board of Directors Section and Independence of External Auditor (Laeven and Levine (2008) [2]; Babatunde and Olaniran (2009) [3] Al-Matari et al. (2012) [4]; Wintoki et al (2012) [5] and Schultz et al (2010) [6].

Ghayad (2008) [7] analyzes the influence of corporate governance and the global performance of Bahrain's sharia banks. It states that Islamic banks should have a shariah advisory board with good knowledge in finance to assist bank management and to develop new products in accordance with sharia regulations. To achieve better corporate governance in sharia banks, it has been proposed to expand the scope of investment account holders who are represented on the board of banks, since investment account holders share risks so they must have seats in directors. 
Farhan et.al (2017) [8] analyzed the effects of corporate governance on corporate performance in the United Arab Emirates. Revealed that in the United Arab Emirates, independent directors are not motivated to improve the performance of the company. the independence of the audit committee negatively affects the performance of the company which can be interpreted as a logical outcome of the negative effects of independent directors. Audit committee members are elected from directors (non-outsider audit committee members) that the correlation between board independence and audit committee independence is predicted. Audit committee meetings and the number of financial experts have no effect on the performance of the company. The above results may be due to lack of experience and auditing ability among audit committees, required to perform the task.

The success of the company also depends on how the ability of management in utilizing the value of intangible assets. For that it is important to do assessment and measurement of intangible assets, including intellectual capital (IC) which is an important element for the company in the creation of corporate value (profitability) and won the value. the importance of Intellectual Capital (IC) investment has been recognized because knowledge assets can affect the company's long-term competitive advantage and in the creation of corporate value (Lev, 2001, Lev, 2004, Cabello-Medina et al., 2011)[9]. Furthermore, Intellectual Capital (IC) is an important source of corporate innovation and human development through knowledge sharing (European Commission, 2010, European Commission, 2013, Nonaka and Takeuchi, 1995) [10].

The reason for using these two variables simultaneously in improving the company's financial performance, because there are still very few studies using both variables simultaneously. Chunghuey and Mao-Chang (2008) [11] suggest that adding variable intellectual

capital into the company's valuation model increases the explanatory power of firm value. Therefore, investors should consider adding intellectual capital and financial capital to the financial statements to evaluate firm values. Ahmed and Duellman (2007) [12] also found that when a company has a high proportion of external directors, conservative in accounting is higher. Therefore, the management of the company is better, and has a beneficial effect on the value of the company.

From several studies it is known that the measurement of company performance or performance many financial discussion only about intellectual capital only. The most commonly used method is Value Added Intellectual Coefficient (VAIC ${ }^{T M}$ ). On the other hand performance measurement is often discussed that is only internal factors of corporate organs in good corporate governance. While the ratio of financial performance for 
Islamic Banking is the Islamicity Performance Index is still a bit that examines especially those that relate to Intellectual Capital VAIC ${ }^{T M}$ method and internal factors of corporate organs in good corporate governance.

Discussion on the Islamicity Performance Index developed by Shahul Hameed et. al. (2004) [13] ie measurement in terms of sharia objectives. The researchers used only a few components of the measurable Islamicity performance index to see the financial performance in accordance with sharia objectives. Intellectual capital is an intangible asset that is very interesting to be studied, especially if it is associated with good corporate governance role and also look at financial performance in terms of sharia objectives. Discussion of this study is felt indispensable for the company's wisdom in achieving goals and in the development of science.

Because of some of the above, the researcher wants to verify the influence of Good Corporate Governance on Intellectual Capital Performance (IC) of the company, expand the company's Intellectual Capital (IC) reference which impact to company's financial performance, and analyze the impact of Good Corporate Governance (GCG) and Intellectual Capital (IC) to the company's financial performance.

\section{Review Literature}

\subsection{Financial performance}

The performance of the profit referred to in this study is the financial performance seen from the profitability of a company. According to Greuning and lqbal (2011) [14] many factors can affect the profitability of a bank. In some cases, inflation may increase operating costs faster than the revenue received. "Fahmi (2012) [15] states financial performance is an analysis conducted to see how far a company has implemented by using the rules of financial implementation in a good and right".

In measuring profitability there are three types of measurements that can be used. These three ratios are the best known and most widely used measure among other financial ratios. In every form, this ratio is meant to measure how efficiently a company has used assets and manages its operations. The focus of this group is on the final outcome, ie net income (Ross et al, 2009) [16].

According to Weygandt et al (2009) [17]. Assets are resources owned by a business. Assets are used in the execution of activities, such as production, consumption and buying and selling. A common characteristic of assets is the ability to provide services or benefits in the future. Modern bankers pay great attention to the results of ratio analysis. 
Banks typically manage profitability by trying to exceed the market average and maintain a stable and predictable rate of return, which in turn attracts investors.

\subsection{Intellectual capital}

Bontis et al. (2000) [18] stated that in general, the researchers identified three main constructs of IC, namely: human capital (HC), structural capital (SC), and customer capital (CC). According to Bontis et al. (2000) [18], HC simply represents the individual knowledge stock of an organization represented by its employees. $\mathrm{HC}$ is a combination of genetic inheritance; education; experience, and attitude about life and business.

According to Shahi (2010) [19], in a modern economy, intellectual capital is a key resource for realizing a company's competitive advantage. It also plays an important role in the fundamental factors of production and trade in accordance with new economic knowledge. Thus, identifying the intellectual capital component as a resource to create an important value for the company.

Tavestge and Ta Lo Goarova (2009) [20] studied the relationship between intellectual capital and performance in Russia. They found that intellectual capital, especially structural capital and human capital, is the primary measure for determining performance. Houvang and Hieuye (2009) [21] studied the relationship between intellectual capital and performance in technical consulting firms in Taiwan. Their results show that there is a correlation between the three components of intellectual capital and business performance. The highest correlation is related to human capital and customer. In addition, they found a positive correlation between the components of intellectual capital (customer capital, human capital and structural capital).

Nadeem et al (2017) [22] analyzed the dynamic relationship between intellectual capital and firm performance in the BRICS economy, stating that the efficiency of intellectual capital is significantly related to ROA and ROE. Furthermore, human, structural and physical capital has a positive value and significant impact on company performance. While the theory of resource dependence and learning theory, emphasizes the importance of intellectual capital for corporate performance.

The VAIC ${ }^{T M}$ method, developed by Pulic (1998) [23], is designed to provide information about the value creation efficiency of tangible assets and intangible assets owned by the company. This model begins with the company's ability to create value added (VA). Value added is the most objective indicator for assessing business success and demonstrating the company's ability in value creation (Pulic, 1998) [23]. 
The intellectual capital relationship with the company's financial performance has been empirically verified by several researchers in various approaches in several countries. Firer and Williams (2003) [24] examine VAIC ${ }^{T M}$ relationships with company performance in South Africa. Chen et al. (2005) [25] used the Pulic (VAIC ${ }^{T M}$ ) model to examine the relationship between IC and market value and company financial performance using a sample of public companies in Taiwan.

There have been several previous studies in various countries that prove the existence of IC reporting practices in the company's annual financial statements with various disclosure formats (eg by: Bontis et al., 2000 [18]; Guthrie et al., 2006) [26]. The concept of value added intellectual coefficient (VAIC ${ }^{T M}$ ) on IC measurement from human capital side is presented by Esfahani (2012) [27], Astuti and Sabeni (2005) [28], Malekian and Zaree (2010) [29], Green (2007) [30], Rodgers \& Housel (2009) [31], Tan, Plowman, \& Hancock (2007) [32].

\subsection{Good corporate governance (GCG)}

Good corporate governance, which in modern terminology is called Good Corporate Governance. Corporate Governance can be defined as a process and structure used by company organs (Owners of Shares / Capital Owners, Commissioners / Board of Trustees, and Directors) to improve business success and corporate accountability in order to realize shareholder value over the long term while maintaining the interest of other stakeholders, based on legislation and ethical values (Sutedi, 2011) [33].

Sharia Supervisory Board (DPS) is a board in charge of giving advice and advice to the board of directors and oversees the bank's activities to conform with sharia principles. Members of DPS should consist of experts in the field of muamalah sharia which also has general knowledge of banking. Membership requirements of DPS are stipulated by the National Sharia Council (Sumar'in, 2012) [34]. According to "Othman and Ameer (2015) [35] analyzes the conceptualisation of tasks and the role of auditors in Islamic finance institutions declared lack of detail Shariah auditing and management standards in Islamic countries led to the growth of Islamic finance industry becoming unhealthy, and the lack of seriousness of sharia-trained auditors".

Hamza (2013) [36] examines the links between Shariah compliance, sharia supervision and the effectiveness of sharia governance in Malaysia. The independence of Islamic councils in monitoring missions and consistency of sharia decisions is a major component of an efficient sharia governance structure. Shariah centralized management system, basically beneficial for the company in terms of effectiveness and credibility 
of sharia banks. Sharia compliance allows sharia banks to consolidate their differentiation factors to support their reputation and credibility. Meanwhile Pathan et al., (2008) [37] Increased expertise is another important mechanism for effective corporate performance.

Al-Matari et al. (2012) [38] summarizes corporate governance practices in Saudi Arabia. This study focuses on corporate governance mechanisms (such as Board composition, CEO duality, board size, audit committee independence, audit committee activity and audit committee size) impact on company performance. The study concludes that the lack of relevant research is available in corporate governance in Saudi Arabia. Mechanisms such as audit committees and boards of directors are inefficient due to lack of independence and members.

The implementation of GCG is a form of accountability of sharia banks to the community that a bank is well managed, professional and prudent by striving to increase shareholder value without ignoring the interests of other stakeholders (Machmud \& Rukmana, 2009) [39]. Susanto (2011) [40] said Good Corporate Governance in Islam should refer to the principles of: monotheism, taqwa and ridha, benefit and equilibrium (Balance and justice). Good Corporate Governance is run not only as a form of management accountability to the owners of capital, but more on the basic needs of every Muslim to run the Islamic law as a whole and perfect.

Thus, the implementation of GCG principles in sharia banking should refer to the provisions of the existing positive law. In addition, he also must apply the principles of sharia so that ultimately obtained the governance of the bank in addition to providing benefits for the stakeholders, also continue to run on the rail / corridor sharia (Machmud \& Rukmana, 2009) [41].

\subsection{Hypothesis}

Based on the theoretical background that has been presented, it can be drawn hypothesis as follows:

H1: The role of Good Corporate Governance (responsibilities and capabilities of the Sharia Supervisory Board, Independence and External Auditor's Ability, Involvement of Investment Account Holders in the Board of Directors) influences the Financial Performance of Sharia BankingCompanies.

H2: The role of Good Corporate Governance (responsibility and ability of Sharia Supervisory Board, Independence and External Auditor's Ability, Involvement of Investment Account Owner in Board of Directors) influences Intellectual Capital Performance 
H3. Intellectual Capital (physical capital, human capital and structural capital) affects the Financial Performance of Sharia Banking Companies.

\subsection{Research methods}

This study examines Good Corporate Governance, three elements of VAICTM (physical capital, human capital and structural capital) and measures of corporate financial performance. The correlation, regression, and ANOVA tests were applied to examine the contribution of various factors of the Good Corporate Governance mechanism. Intellectual Capital referred to in this research is IC performance measured by value added created by physical capital (VACA), human capital (VAHU), and structural capital (STVA). The combination of these three value added is symbolized by the name VAIC. The formulation and calculation steps of VAIC ${ }^{T M}$ are as follows: Step One: Calculating Value Added (VA).

Step Two: Calculating Value Added Capital Employed (VACA). Third Stage: Calculating Value Added Human Capital (VAHU).

\section{References}

[1] Abdolmohammadi, M.J. 2005. "Intellectual capital disclosure and market capitalization". journal of Intellectual Capital. Vol. 6 No. 3. pp. 397-416.

[2] Ali, Zainuddin. 2010. Hukum Perbankan Syariah. Jakarta: Sinar Grafika.

[3] Bontis, N. 1998a. "Intellectual capital questionnaire". Available online at: www.bontis. com. (diakses oktober 2016).

[4] _ 1998b. "Intellectual capital: an exploratory study that develops measures and models". Management Decision. Vol. 36 No. 2. p. 63.

[5] Babatunde, M.A. and Olaniran, O. (2009), "The effects of internal and external mechanism on governance and performance of corporate firms in Nigeria", Corporate Ownership Control, Vol. 7 No. 2, pp. 330-344

[6] Chen, M.C., S.J. Cheng, Y. Hwang. 2005. "An empirical investigation of the relationship between intellectual capital and firms' market value and financial performance". Journal of Intellectual Capital. Vol. 6 NO. 2. pp. 159-176

[7] Firer, S., and S.M. Williams. 2003. "Intellectual capital and traditional measures of corporate performance". Journal of Intellectual Capital. Vol. 4 No. 3. pp. 348360.

[8] Fauzi. 2016. "Kinerja dan Langkah Strategis Pengembangan Perbankan Syariah di Indonesia". Prosiding Keuangan dan Perbankan Syariah. ISSN. 2460-6561. 
[9] Ghozali, I. 2006. Structural Equation Medeling; Metode Alternatif dengan PLS. Badan Penerbit Undip. Semarang.

[10] Greuning \& Iqbal. 2011. Analisis Resiko Perbankan Syariah. Jakarta: Salemba Empat. Harrison, S., and P.H. Sullivan. 2000. "Profitting form intellectual capital; Learning from leading companies". Journal of Intellectual Capital. Vol. 1 No. 1. pp. 3346.

[11] Kubo, I., and A. Saka. 2002. "An inquairy into the motivations of knowledge workers in the Japanese financial industry". Journal of Knowledge Management. Vol. 6 No. 3. pp. 262-271.

[12] Laeven, L. and Levine, R. (2008), "Complex ownership structures and corporate valuations", Review of Financial Studies, Vol. 21 No. 2, pp. 579-604.

[13] Muttaqin, Hadi. 2013. Teori Kepemilikan Perusahaan dan Pengertian Kepemilikan Perusahaan. Pustakabakul.blogspot.co.id/2013/06/teorikepemilikan-perusahaandan.html. Diakses pada 2 Juni 2016.

[14] Pulic, A. 1998. "Measuring the performance of intellectual potential in knowledge economy". Paper presented at the 2nd McMaster Word Congress on Measuring and Managing Intellectual Capital by the Austrian Team for Intellectual Potential.

[15] Rustam, Bambang, Rianto. 2013. Manajemen Resiko Perbankan Syariah di Indonesia. Jakarta: Salemba Empat.

[16] Riahi-Belkaoiu, A. 2003. "Intellectual capital and firm performance of US multinational firms: a study of the resource-based and stakeholder views". Journal of Intellectual Capital. Vol. 4 No. 2. pp. 215-226.

[17] Shahul Hameed et.al. 2004. Alternative Disclosure \& Performance Measures For Islamic Banks dalam Proceeding of The Second Conference on Administrative Science: Meeting The Challenges of The Globalization Age. Dahran, Saudi Arabia, 2004.

[18] Sutedi, Adrin. 2011. Good Corporate Governance. Jakarta: Sinar Grafika.Sumar'in. 2012. Konsep Kelembagaan Bank Syariah. Yogyakarta: Graha IImu.

[19] Yaya, Rizal. 2014. Akuntansi Perbankan Syariah Teori dan Praktik Kontemporer. Jakarta: Salemba Empat. 